\title{
広域圏内市町村の通勤・転居構造とその変化に関する考察 \\ 典型状態合成法の提示と適用 \\ Analysis of the Commutation and House Moving Structures and Their Changes among Municipalities in County Level Areas
}

Presentation and Application of the Method to Synthesize Typical Situations

\author{
能美 誠* \\ Makoto NOHMI* \\ (*鳥取大学) \\ (*Tottori University)
}

\section{I 問題意識}

農村地域の定住性を高めるためには, 就業条件の確保 や居住環境の整備が重要だが，それを企図した取り組み は, モータリゼーションの普及も相俟って, “平成の大 合併前” の昭和後期市町村を複数まとめたエリアである 広域圈を対象として行われることが多い。広域圈を対象 としたこれまでの生活環境整備構想や取り組みの流れと 特徵をみると, 以下のように整理できる。

まず, 1969 年に閣議決定された新全総では, 自動車の 普及や生活の広域化を踏まえて, 市町村のエリアを超え る広域開発行政を推進していく考え方が提示された。そ こでは，「圈域内に施設を適正に配置し，住民に一定水準 の生活環境」を提供する圏域として「広域生活圈」が位 置づけられ〔国土庁 ${ }^{1)}$ ]，それを具体化する施策として， 同年に自治省から「広域市町村圏」構想, 建設省からは 「地方生活圈」構想が出された注1)。つぎに, 三全総では 「定住圈」構想が提示され, 「市町村は, 広域生活圈の施 策等の実績を踏まえて, 生活環境の整備と地域振興を中 心に, 総合的居住環境の整備を進める」一方, 「都道府県 は，市町村と連携して国土資源の利用，管理，交通ネッ トワークの形成, 居住の安定性を確保するための根幹的 施設の整備等を中心に, 計画的に定住圏の整備を推進す る」ことが企図された〔国土庁 ${ }^{2)}$ 〕四全総においては, 広域圈構想は具体的には提示されなかったが,「多極分散 型国土」の構築に際して,「生活の圈域（定住圈）を基礎 的な単位」として捉えている〔国土庁 ${ }^{3)}$ 〕その後，21 世紀の国土のグランドデザインでは,「多自然居住地域」 の生活圏域整備が打ち出され, そこでは「中小都市等は 圈域の中心都市として, 基礎的な医療と福祉, 教育と文 化, 消費等の都市的サービスや身近な就業機会を周辺の 農山漁村に提供する」ことや, 多自然居住地域では, 「質 の高い生活と就業を可能にするため, 農林水産業や地域
の持つ自然や文化等資源を総合的に活用した新しい産業 システムの構築, 高度な情報通信の活用による立地自由 度の高い産業の育成」が企図されている〔国土庁 ${ }^{4)}$ 〕さ らに, 現在は「定住自立圈」制度の下で広域圈の整備が 進みつつあるが，そこでは中心市宣言を行った都市が周 辺の市町村（群）と協定を締結することにより（なかに は 1 市町村だけの定住自立圈も存在する), 医療, 福祉, 教育, 産業振興, 地域公共交通, 交通インフラ整備, 等 のさまざまな分野で生活基盤・生活機能の強化を図る取 り組みが行われている。「定住自立圈」の場合, 市町村の 複数の定住自立圈への所属や, 都道府県境界をまたいだ 圈域形成も認められている点に特徴がある注 2)。

なお, 以上の各種広域圈構想には, 広域圈の面積や市 町村数等についての具体的規定はないが，基本的には中 心都市とそれを取り巻く周辺地区・市町村群という地域 範囲が認識されており，おおむね平成の大合併前におけ る複数の昭和後期市町村で構成されるエリアと捉えるこ とができる。また, 広域連合の活動や定住自立圈の取り 組み内容をみると, 消防活動, ゴミ処理, 休日医療サー ビスの提供, 福祉事業の共同実施, 図書館の相互利用, 産業振興への共同的取り組み, 地域公共交通の維持・運 営等, 周辺市町村も含めて広域圈内全域を対象とした生 活機能の維持・向上をはかるための広域連携活動が多い 状況にある。

以上のように, 広域圈の整備に関する構想・計画は, 時代の推移とともに生活環境整備の重点に変化は認めら れるが，そこで設定される広域的な地域範囲は，各市町 村単独では対応が困難, または複数の自治体が一緒に取 り組んだほうが有効性の高い生活環境整備や環境管理上 のハード, ソフト両面の課題の解決を目的として設定さ れる複数の昭和後期市町村を対象としたエリアという捉 え方ができる。時代が変化しても, 広域圈を対象とした 生活環境整備の重要性に変わりはないものといえる。な 
お, 複数の昭和後期市町村で構成されるエリアには,「広 域市町村圈」「定住圈」等, さまざまな名称が利用され てきたが，本稿では「広域圈」という用語を用いる。

また, 広域圈は通勤や転居が行われる地域範囲として 重要な役割を備えており, 地域住民が中長期的に居住す る空間として, 生活環境整備上で重要な位置づけにある。 そのため, 広域圈内での人の流動状況とその変化は, 生 活環境整備エリアとしての広域圈の位置づけの変化や, 広域圈内の定住機能向上方策を考えるうえで重要な検討 事項である。そこで, 本稿では通勤と転居という2つの 主要な流動現象を対象として, 広域圈内の人の流動状況 とその変化を分析し, 広域圈の定住機能向上をはかるう えで重要な環境整備上の留意点を提示していく。

ところで, 広域圈内の人の流動現象は, 通勤, 転居以 外にも買物, 通院, 通学, 文化・スポーツ活動等, 多様 なものが存在するが, 通勤, 通学, 転居以外の流動現象 は，全国的に利用可能な統計資料に乏しいこと，また， 通学に関しても, 通学先が学校の設置場所や学区制度等 の教育行政的要因によって影響を受ける部分があるため, ここでは分析対象から除いている。

従来から通勤・通学や人口移動（転居）等を通じた広 域圈に関わる地域住民の流動状況を考察した研究は多く みられる。たとえば, 宮沢・和田 ${ }^{71}$ は市町村を単位地区 として, 関東地方 ・東北地方の広域圈内市町村相互間の 人口移動構造を考察しているが, 対象年次は単年時に限 定されている。一方, 菅 ${ }^{81}$ は 1995〜2005 年を対象にして 九州の通勤圈を分析しているが，広域圈内の通勤流動の 考察は, 主に中心都市との関係に限定されており, 広域 圈内の流動状況に関する分析は十分に行われていない。 さらに, 劉・佐藤・小林・韓・李・金 ${ }^{9}$ はデータの制約 から 10 人以上の市町村間通勤通学流動データを利用し て, 大分県の都市圈を 1975 年〜1995 年にかけて分析し ている。

このように, 従来の研究は一時点を対象としたもの, あるいはある程度の期間を対象とはしているものの, 広 域圈内の流動状況を一部の市町村間や中心都市との関係 を中心にして分析しているものが多く, 広域圈内におけ る人の流動を, 中長期的な変化を対象として, かつさま ざまな市町村間の流動まで考慮している研究は不十分で ある。そこで, 本稿では全国から８つの広域圈を取り上 げて, 最近の 20〜25 年間を対象に, 時間の推移にともな う広域圈構成市町村間の通勤流動や転居流動の変化態様 を分析する。

なお, 本稿では, 分析に際して, 流動状況の変化の特 徵が把握しやすいように, 実際の流動状況を, 流動状況 に関する複数の典型状態の合成により表現できる方法
（以下では「典型状態合成法」とよぶ）を提示し，その 方法を利用して, 各広域圈における通勤流動や転居流動 の変化方向を検討するとともに，当該方法の有用性を実 証していくことも目的としている。

\section{II 分析対象広域圈と分析方法}

\section{1 分析対象広域圏}

本稿で分析対象とする広域圈とその構成市町村は以下 の8つである。ここでは広域圈の中心市町村や地域(郡) 名を用いて表現する(下線を引いた都市が中心市町村)。 (1)旭川圈（北海道 : 9 市町村 : 旭川市, 鷹栖町, 東神楽 町, 当麻町, 比布町, 愛別町, 上川町, 東川町, 美瑛町) (2)最上圈（山形県: 8 市町村 : 新庄市, 金山町, 最上町, 舟形町, 真室川町, 大蔵村, 鮭川村, 戸沢村)

(3)邑楽圈（群馬県 : 6 市町村 : 館林市, 板倉町, 明和村, 千代田町, 大泉町, 邑楽町)

(4)長生圈（千葉県: 7 市町村: 茂原市, 一宮町, 睦沢町, 長生村, 白子町, 長柄町, 長南町)

(5)加茂圈 (岐阜県 : 8 市町村 : 美濃加茂市, 坂祝町, 富 加町, 川辺町, 七宗町, 八百津町, 白川町, 東白川村) (6)安芸圈 (高知県: 9 市町村: 室戸市, 安芸市, 東洋町, 奈半利町, 田野町, 安田町, 北川村, 馬路村, 芸西村) (7)览湯圈（宮崎県: 7 市町村: 西都市, 高鍋町, 新富町, 西米良村, 木城町, 川南町, 都農町)

8)国頭圈（沖縄県：12 市町村：名護市, 国頭村, 大宜味 村, 東村, 今帰仁村, 本部町, 恩納村, 宜野座村, 金武 町, 伊江村, 伊平屋村, 伊是名村)

本稿では, 1990 年〜2015 年を分析対象とするが注3), この 8 広域圈はいずれも当該期間に市町村合併が行われ ておらず, 継続して同一市町村群が分析に利用可能なこ と, また, 各広域圈とも広域市町村圈（事務）組合の活 動, 定住自立圈形成協定の締結, 等の組織的取り組みが 行われており, 実態的にも一つの圈域として認知可能で あること，等の理由により，分析対象に選定した。

なお，国頭圈には名護市・国頭郡の町村のほか，島尻 郡の伊平屋村と伊是名村も含んでいる。このうち, 伊江 村, 伊平屋村, 伊是名村の 3 村は沖縄本島とは繋がって いない島嶼の村である。

\section{2 典型状態合成法}

上述のように，本稿では典型状態合成法を提示・使用 する。その方法は以下の通りである。

いま, 広域圈（仮想例）を構成する市町村数 $\mathrm{n}$ が 5 つ であるとして, 市町村相互閒の流動者数（通勤者数や転 居者数）が表 1 の通りであるとする。表 1 は, 行（表側） 
から列（表頭）への流動者数を示している。たとえば，E 市（行）とF 町 (列) の交点にある 40 名（表 2 内の網掛 け数值）は, E 市から F 町への流動者数を意味する。

\section{表 1 仮想例における市町村間流動者数}

Table 1 The number of moving peoples between any two municipalities in a supposed case

\begin{tabular}{c|c|r|r|r|r|r}
\hline \hline & E 市 & F 町 & G 町 & H 村 & I 村 & 行和 \\
\hline E 市 & 400 & 40 & 30 & 20 & 10 & 500 \\
\hline $\mathrm{F}$ 町 & 160 & 200 & 24 & 12 & 4 & 400 \\
\hline $\mathrm{G}$ 町 & 120 & 15 & 150 & 9 & 6 & 300 \\
\hline $\mathrm{H}$ 村 & 50 & 10 & 10 & 130 & 0 & 200 \\
\hline $\mathrm{I}$ 村 & 20 & 7 & 3 & 0 & 70 & 100 \\
\hline
\end{tabular}

表 2 仮想例における市町村間流動者比率 $\left(\mathrm{D}_{\mathrm{i} j \mathrm{j}}\right)$

Table 2 The ratio of moving peoples between any two municipalities in a supposed case $\left(D_{i j}\right)$

\begin{tabular}{l|l|l|l|l|l|l}
\hline \hline & E 市 & F 町 & G 町 & H 村 & I 村 & 行和 \\
\hline E 市 & 0.80 & 0.08 & 0.06 & 0.04 & 0.02 & 1.00 \\
\hline F 町 & 0.40 & 0.50 & 0.06 & 0.03 & 0.01 & 1.00 \\
\hline G 町 & 0.40 & 0.05 & 0.50 & 0.03 & 0.02 & 1.00 \\
\hline H 村 & 0.25 & 0.05 & 0.05 & 0.65 & 0.00 & 1.00 \\
\hline I 村 & 0.20 & 0.07 & 0.03 & 0.00 & 0.70 & 1.00 \\
\hline
\end{tabular}

表 3 典型状態 $\alpha$ における流動者比率設定值 $\left(A_{i j}\right)$

Table 3 The ratio of moving peoples between any two municipalities in archetype case $\alpha\left(\mathrm{A}_{\mathrm{ij}}\right)$

\begin{tabular}{l|l|l|l|l|l|l}
\hline \hline & $E$ 市 & $F$ 町 & $G$ 町 & H 村 & I 村 & 行和 \\
\hline E 市 & 1.00 & 0.00 & 0.00 & 0.00 & 0.00 & 1.00 \\
\hline F 町 & 0.00 & 1.00 & 0.00 & 0.00 & 0.00 & 1.00 \\
\hline$G$ 町 & 0.00 & 0.00 & 1.00 & 0.00 & 0.00 & 1.00 \\
\hline H 村 & 0.00 & 0.00 & 0.00 & 1.00 & 0.00 & 1.00 \\
\hline I 村 & 0.00 & 0.00 & 0.00 & 0.00 & 1.00 & 1.00 \\
\hline
\end{tabular}

表 4 典型状態 $\beta$ における流動者比率設定值 $\left(B_{i j}\right)$ Table 4 The ratio of moving peoples between any two municipalities in archetype case $\beta\left(B_{i j}\right)$

\begin{tabular}{l|l|l|l|l|l|l}
\hline \hline & $E$ 市 & F 町 & $G$ 町 & H 村 & I 村 & 行和 \\
\hline E 市 & 1.00 & 0.00 & 0.00 & 0.00 & 0.00 & 1.00 \\
\hline F 町 & 1.00 & 0.00 & 0.00 & 0.00 & 0.00 & 1.00 \\
\hline$G$ 町 & 1.00 & 0.00 & 0.00 & 0.00 & 0.00 & 1.00 \\
\hline H 村 & 1.00 & 0.00 & 0.00 & 0.00 & 0.00 & 1.00 \\
\hline I 村 & 1.00 & 0.00 & 0.00 & 0.00 & 0.00 & 1.00 \\
\hline
\end{tabular}

表 5 典型状態 $\gamma$ における流動者比率設定 $\left(C_{i j}\right)$ Table 5 The ratio of moving peoples between any two municipalities in archetype case $\gamma\left(\mathrm{C}_{\mathrm{ij}}\right)$

\begin{tabular}{l|l|l|l|l|l|l}
\hline \hline & E 市 & F 町 & G 町 & H 村 & I 村 & 行和 \\
\hline E 市 & 0.20 & 0.20 & 0.20 & 0.20 & 0.20 & 1.00 \\
\hline F 町 & 0.20 & 0.20 & 0.20 & 0.20 & 0.20 & 1.00 \\
\hline G 町 & 0.20 & 0.20 & 0.20 & 0.20 & 0.20 & 1.00 \\
\hline H 村 & 0.20 & 0.20 & 0.20 & 0.20 & 0.20 & 1.00 \\
\hline I 村 & 0.20 & 0.20 & 0.20 & 0.20 & 0.20 & 1.00 \\
\hline
\end{tabular}

いま, 各市町村から全市町村に対する流動者数合計 (行 和）の違いによる市町村の影響を除去するため，すべて の要素值をそれぞれの行和で割ると, 表 2 のようになる。 表 2 は, 各市町村による流動者数の違いを捨象するため, 全市町村（自市町村を含む）への流動者数を比率で表現 したものである。分析では，この比率を使用する。その 際には, i 市町村から j 市町村への流動者比率をDijで 表す。

つぎに, 流動状況に関する 3 つの典型状態を設定する。 第 1 は, “流動者はすべて自市町村内で流動する”とい う典型状態である（典型状態 $\alpha$ )。この状態を表示する と, 表 3 の通りである。

典型状態 $\alpha$ の場合, すべて自市町村内流動であるため, かりにこうした流動状況が認められる場合には，当該流 動現象に関しては広域圈の意義は存在しないが，一つの 典型状態としては意味のある姿であり, 実際の流動状況 がこの状態にどの程度近いか（遠いか）を検討すること は重要である。本稿では, 典型状態 $\alpha$ における $i$ 市町村 から $\mathrm{j}$ 市町村への流動者比率設定值を $A_{i j}$ で表す。

つぎに, 第 2 の典型状態（典型状態 $\beta$ ）として, 流動 者の流動先はすべて中心市町村の場合を設定する。この 仮想例の広域圈中心市町村は $\mathrm{E}$ 市であるとすると, その 典型状態は表 4 のように表現できる。

典型状態 $\beta$ の場合, 広域圏内の市町村は, 当該流動現 象に関しては, 中心市町村に対してのみ繋がりを有する 状態を意味しており，広域圈内のネットワーク状況に関 する一つの典型状態を表すものといえる。本稿では, 典 型状態 $\beta$ における $\mathrm{i}$ 市町村から $\mathrm{j}$ 市町村への流動者比率 設定值を $\mathrm{B}_{\mathrm{i} j}$ で表す。

最後に, 第 3 の典型状態（典型状態 $\gamma$ ) としては, 広 域圈内のどの市町村も全市町村に均等に流動する状態を 設定する。この状態は表 5 のように表現できる。

この仮想例の場合, 典型状態 $\gamma$ では, すべての流動值 は 0.20 で同一となる。流動者数合計自体は各市町村によ り異なるが，どの市町村に対しても同人数が流動するた 
め, どの市町村においても流動者数比率は同じである。 本稿では, 典型状態 $\gamma$ における $i$ 市町村から $j$ 市町村 の流動者比率設定值を $\mathrm{C}_{\mathrm{ij}}\left(\forall \mathrm{i}, \mathrm{j}, \mathrm{C}_{\mathrm{ij}}=1 / \mathrm{n}\right)$ で表す。 そこで, 以上 3 種類の典型状態を採用して, 実際の流 動者比率（表 2) が 3 種類の典型状態をどのようなウエ イトで合成した状態に近いのかを表現してみる。

いま, i 市町村から j市町村への流動者比率に関して, 典型状態 $\alpha$ に, 典型状態 $\beta$ に , 典型状態 $\gamma$ に $\mathrm{z}$ と いうウエイトをそれぞれ付与すると, $A_{i j} x+B_{i j} y+C_{i j} z$ は各 典型状態が意味する流動者比率に, それぞれに対応する ウエイトを乗じて加算した合成值を意味する。そこで, この合成值と実際の流動者比率 (Dij) との間の偏差をす べての市町村の組合せに対して計算し, それらすべての 市町村の組合せに関する偏差 2 乗值の合計を $\mathrm{S}$ とすと, S はつぎのように表現できる。

$$
\mathrm{S}=\Sigma_{\mathrm{i}} \Sigma_{\mathrm{j}}\left\{\left(\mathrm{A}_{\mathrm{ij} X} \mathrm{X}+\mathrm{B}_{\mathrm{ij}} \mathrm{y}+\mathrm{C}_{\mathrm{ij}} \mathrm{Z}\right)-\mathrm{D}_{\mathrm{ij}}\right\}^{2} \quad(\mathrm{i}=1 \sim \mathrm{n}, \quad \mathrm{j}=1 \sim \mathrm{n})
$$

(式 1)

すると, 本稿の目的に即して考えると, 各典型状態に 付与するウエイト（x, y, z）は， S の值が最小（極小） となるように設定すればよい。そのためには,

\section{$\partial \mathrm{S} / \partial \mathrm{x}=0, \partial \mathrm{S} / \partial \mathrm{y}=0, \partial \mathrm{S} / \partial \mathrm{z}=0$}

という 3 つの条件式を求めて, そこから得られる $\mathrm{x}, \mathrm{y}$, z の值を採用する注 4 )

典型状態合成法では, 実際の流動状況を $3 つ$ 典型状 態の 1 次結合により近似的に表現することを目的として いる。その場合, ある広域圈内の流動現象に関して, た とえば自市町村内流動 $(\alpha)$ の要素が相対的に強まると, 中心市町村流動（ $\beta$ ）または均等流動（ $\gamma)$, あるいはそ の両方の要素が相対的に弱まることになるため, $\mathrm{x}$ 值, $\mathrm{y}$ 值, $\mathrm{z}$ 值は相互依存関係のなかでそれぞれの值が決まる ことに留意されたい。

この仮想例の場合は, 合計 25 個 $(=5 \times 5)$ の発地・着 地市町村の組合せを対象に目的関数（S）を設定して x, y, z の值を求めることになる。計算した結果は, $\mathrm{x}=0.538$, $\mathrm{y}=0.263, \mathrm{z}=0.200$ となった。すなわち, この仮想例の場 合, 自市町村内流動（典型状態 $\alpha$ ）の要素が最も強く, 0.538 のウエイト,ついで中心市町村流動 (典型状態 $\beta$ ) の要素が 0.263 のウエイトで続き, 均等流動（典型状態 $\gamma$ ）の要素には 0.200 のウエイトがついた。表 1 からも わかるように, 各市町村とも自市町村内流動者数が一番 多いことから,典型状態 $\alpha$ のウエイトが相対的に大きく なっている。一方, 中心市町村流動は, 各市町村におい て自市町村内流動に次いで大きな人数となっているが, 中心市町村流動人数は自市町村内流動人数に比べるとあ る程度大きな差異があるため, 典型状態 $\beta$ に付与された ウエイトは $\alpha$ に付与されたウエイトに比較してかなり
小さな值になったものと理解できる。また，表 2 から均 等流動的要素は乏しいことがわかるが，自市町村や中心 市町村以外への流動もある程度は認められることから， 転掲示状態 $\gamma$ に対寸るウエイトも 0.200 に達している。 なお，このウエイトを採用した場合には，広域圈全体 として $\left(\mathrm{A}_{\mathrm{ij}} \mathrm{x}+\mathrm{B}_{\mathrm{ij}} \mathrm{y}+\mathrm{C}_{\mathrm{ij}} \mathrm{z}\right)$ と $\mathrm{D}_{\mathrm{ij}}$ との乘離がもっとも小さく なるが, 乘離自体は残るため, その乘離の程度を乘離率 指標により把握することにする。ここでは, 乘離率 (Er) をつぎの式で計算する。

$\mathrm{Er}=\sqrt{\mathrm{S} / \mathrm{n}^{2}} /\left\{\left(\sum_{\mathrm{i}} \Sigma_{\mathrm{j}} \mathrm{D}_{\mathrm{ij}}\right) / \mathrm{n}^{2}\right\} \times 100 （ \mathrm{n}=$ 市町村数）（式 2） これは, 乘離量に関する平方平均を流動者比率平均で 割った值である。

ところで，x，y，z は個々の市町村に対しても算出可 能である。すなわち，i 市町村から広域圏内全市町村へ の流動比率に限定して（この仮想例の場合は５個）S を 設定すると，市町村単位でも 3 種類の典型状態に関する 同様のウエイトが求められる。

$$
\mathrm{S}=\Sigma_{\mathrm{j}}\left\{\left(\mathrm{A}_{\mathrm{ij}} \mathrm{X}+\mathrm{B}_{\mathrm{ij}} \mathrm{y}+\mathrm{C}_{\mathrm{ij}} \mathrm{z}\right)-\mathrm{D}_{\mathrm{ij}}\right\}^{2} \quad(\mathrm{i}=1 \sim \mathrm{n}) \quad(\text { 式 } 3)
$$

ただし, 中心市町村 $\mathrm{p}$ の場合には, $\mathrm{A}_{\mathrm{ip}}=\mathrm{B}_{\mathrm{ip}} \quad(\mathrm{i}=1 \sim \mathrm{n})$ という関係が成立するため, 典型状態 $\alpha$ と $\beta$ は同じ内 容を意味することになり, $\mathrm{x}, \mathrm{y}, \mathrm{z} の 3$ つを求めること はできない。そのため, 中心市町村の場合には典型状態 を $\alpha$ と $\gamma$ の 2 つして, さきに述べたのと同様の方法 でx と z だけを算出する。なお, 以下の分析では, 必要 に応じて市町村単位で算出した $\mathrm{x}, \mathrm{y}, \mathrm{z}$ の值も利用する。

ところで, 流動者比率に関する広域圈内市町村の特徵 は, 単純に $\mathrm{D}_{\mathrm{i} j}$ の值を利用することによっても把握は可 能である。たとえば, 典型状態 $\alpha$ や $\beta$ については, 該 当する $i j$ 市町村の組合せ (表 3 や表 4 で網掛けを施した 市町村の組合せ）を対象に，その流動者比率の全流動者 比率合計に占める割合を計算することによっても把握可 能である。しかし, 広域圈によって市町村数が異なると, 典型状態 $\alpha$ や $\beta$ に該当する市町村の組合せ数が, 広域 圈の全市町村組合せ数に占める割合は変化する。たとえ ば，市町村数が 5 個の広域圏の場合，全組合せ数に占め る典型状態 $\alpha$ や $\beta$ で流動先の対象となる市町村の組合 せも 5 個で, 全市町村組合せ数の 25 個に占める割合は $20 \%$ であるしかし, 市町村数が 6 個の広域圈の場合に は，この割合は $16.6 \%(=6 / 36 \times 100)$ に変化する。そし て,この割合の違いも，典型状態 $\alpha$ や $\beta$ に該当する流 動量（の割合）にも影響を与える可能性がある。このた め, 対象とする流動現象が典型状態 $\alpha$ や $\beta$ が意味する 状況をどの程度反映しているのかを, 市町村数の異なる 広域圈間で比較しょうとすれば, より厳密には, 本稿で 提示する方法のように，市町村数の違いによる影響を受 けない措置を採用して検討することが望ましい。 
対応するセルの值を直接集計・利用する方法の場合, 市町村数 (セル数) の違いが結果に影響を与えるのに比 べると, 典型状態合成法は 3 つの典型状態の 1 次結合比 率を求める方法であり, ある広域圈内の流動現象が全体 としてどのような典型状態の組合せに近いのかを求める ことを主眼としており, その方法自体はセル数值の加算 と集計結果の比較を行わないため, 市町村数（セル数） の違いの影響を直接には受けない。

ただし, 広域圈内の市町村数や広域圈の面積が異なる と, 広域圈内の流動現象が影響を受ける可能性はあるた め, 広域圈間で結果を比較する際には, $\mathrm{x}$ 值, $\mathrm{y}$ 值, $\mathrm{z}$ 值 の小さな差異をもって広域圈相互間の流動構造の違いを 指摘することは避ける必要がある。

また, 中心市町村内での流動の場合は, 自市町村内で の流動という側面と中心市町村への流動という側面の 2 つの側面が認められる。すると, 中心市町村内での流動 量・割合をどちらに含めるのか, あるいはどの程度の比 率で両者に按分するのかという点に関しても, さきの簡 単な方法の場合にはルールを決めて分析する必要がある が注 5), 本稿で提示する方法の場合には, そうした問題も 回避できるメリットがある。

なお，典型状態合成法では広域圈内市町村間の流動の 特徵を相対的観点から把握することを目的としているた め, 流動者数自体の分析は行うことができない。そのた め, 流動者数自体の分析が必要な場合には, 別途, 流動 者数の検討が必要となることには留意を要する。

\section{III 広域圈の通勤・転居構造とその変化}

以上説明した典型状態合成法を利用して, 8 つの広域 圈の流動状況を 3 つの典型状態の一次結合で表現してい く。利用可能な国勢調査データの制約から, 通勤につい ては 1990 年, 1995 年, 2000 年, 2005 年, 2010 年の 5 時点, 転居については 1995 年〜2000 年, 2005 年〜 2010 年, 2010 年〜2015 年の 3 期間を対象とする。なお, 本稿 では，通勤における自宅就業は自市町村内通勤に含めて 扱っている。

表 6 に, 典型状態 $\alpha \cdot \beta \cdot \gamma$ に付与されたウエイト $(x$, y， z）とその推移を示している。これをみると, 通勤の 場合, 典型状態 $\alpha$ のウエイト水準自体は広域圏によって 異なるが, 多くの広域圈においてそのウエイトが低下し てきた注 6)。すなわち, 自市町村内流動という典型状態 $\alpha$ からは離れていく傾向が認められる。他方, 典型状態 $\beta$ と $\gamma$ に付与されたウエイト值は, その水準は低いも のの, 全体的には上昇してきている。したがって, 各広 域圈では, 相対的に市町村外通勤のウエイトが高まり,
広域圈がもつ通勤圈としての重要性は相対的に高まって きたことがわかる。ただし，1990 年と 2010 年を比較す ると, 表 7 に示すように, すべての広域圈において広域 圈内の合計通勤者数は減少している。また, 中心市町村 に限定しても, 最近の 20 年間ではほとんどの広域圏内に おいて中心市町村への通勤者数と転居者数も減少してい る。したがって, 典型状態 $\beta$ と $\gamma$ に付与されたウエイ 卜值の増加は, 基本的には相対的な変化現象である点に も留意が必要である。また，人口に関しても，多くの広 域圈で減少傾向が認められる。

なお, ウエイト y の高低は, 広域圈内における中心市 町村の相対的重要性によって影響を受けている。旭川圈, 最上圈, 長生圈のように, 広域圈内で中心市町村の中心 性が高い広域圏の場合には, y の值は 0.2 台で相対的に 高いが, 安芸圈, 児湯圈のように, 中心市町村の中心性 が弱い広域圏の場合には, y の值は $0.01 〜 0.03$ 程度で相 対的にかなり低い。安芸圈においては室戸市, 児湯圈で は高鍋町が，中心市町村に肉薄する程度に相対的に強い 中心性を有しているため, これらの広域圈では典型状態 $\beta$ の要素はほとんど認められないものといえる。

また, 8 つの広域圈のなかで広域圈内の通勤流動状況 が多様性を備えているのは邑楽圈である。邑楽圈では典 型状態 $\alpha$ のウエイト值が長生圏に次いで小さいほか, $\beta$ よりも $\gamma$ に付与されたウエイト值のほうが大きく,均等 流動的要素が比較的強い。そのため, 広域圈内の市町村 相互間で多面的に通勤流動が展開されている。これは, 邑楽圈の場合, 面積が比較的狭いことのほか, 大泉町の ように中心市町村の館林市以外にも工場が多く立地する 市町村があり，雇用機会が館林市に集中していないこと が，その理由としてあげられる。反対に，国頭圈の場合 は, 典型状態 $\alpha$ のウエイト值が 2010 年においても 0.80 を超えており, 自市町村内流動の典型状態 $\alpha$ に近い。こ れには, 広域圈構成 12 市町村のうち 3 村は島嶼にあり, 他市町村との間で通勤が行い難いことが理由の一つと考 えられる。ただし, 国頭圈においても典型状態 $\alpha$ のウエ イト值は低下傾向にあり, 通勤活動における広域圈の重 要性は相対的に高まりつつある。

ところで, 各広域圈に関して, 通勤流動に関する各市 町村の典型状態のウエイト值も計算したが, その結果に よると, 旭川圏, 最上圈, 長生圈の場合には, 広域圈全 体だけでなく，その構成市町村においてもウエイト值は $\mathrm{x}>\mathrm{y}>\mathrm{z}$ の順序の場合が多く，通勤構造は構成市町村間 で等質的である。ただし, 異なった特徴をもつ広域圈も ある。表 6 の下段には, 邑楽圏を対象として, 2010 年時 点の通勤流動に関する各市町村の典型状態のウエイト值 を示している。これをみると，市町村により典型状態に 
表 6 典型状態の合成ウエイトとその推移

Table 6 The weights endowed with three archetype cases and their trends

\begin{tabular}{|c|c|c|c|c|c|c|c|c|c|}
\hline & & \multicolumn{5}{|c|}{ 通勤 } & \multicolumn{3}{|c|}{ 転＼cjkstart居 } \\
\hline & 年次・期間 & 1990 年 & 1995 年 & 2000 年 & 2005 年 & 2010 年 & $1995-2000$ 年 & $2005-2010$ 年 & $2010-2015$ 年 \\
\hline 旭 & $\alpha$ & 0.788 & 0.752 & 0.729 & 0.703 & 0.683 & 0.553 & 0.528 & 0.550 \\
\hline 川 & $\beta$ & 0.187 & 0.216 & 0.232 & 0.254 & 0.268 & 0.378 & 0.400 & 0.366 \\
\hline \multirow[t]{2}{*}{ 圈 } & $\gamma$ & 0.026 & 0.032 & 0.039 & 0.043 & 0.049 & 0.069 & 0.072 & 0.083 \\
\hline & 誤差率 & $37.8 \%$ & $49.5 \%$ & $55.8 \%$ & $63.0 \%$ & $65.7 \%$ & $17.0 \%$ & $50.5 \%$ & $24.1 \%$ \\
\hline \multirow{4}{*}{$\begin{array}{l}\text { 最 } \\
\text { 上 } \\
\text { 圈 }\end{array}$} & $\alpha$ & 0.770 & 0.716 & 0.677 & 0.646 & 0.628 & 0.484 & 0.438 & 0.504 \\
\hline & $\beta$ & 0.172 & 0.214 & 0.240 & 0.257 & 0.267 & 0.386 & 0.373 & 0.328 \\
\hline & $\gamma$ & 0.058 & 0.070 & 0.084 & 0.098 & 0.105 & 0.129 & 0.189 & 0.168 \\
\hline & 誤差率 & $24.5 \%$ & $26.8 \%$ & $29.3 \%$ & $29.9 \%$ & $29.1 \%$ & $50.1 \%$ & $52.9 \%$ & $39.3 \%$ \\
\hline \multirow{4}{*}{$\begin{array}{l}\text { 邑 } \\
\text { 楽 } \\
\text { 圈 }\end{array}$} & $\alpha$ & 0.684 & 0.655 & 0.625 & 0.599 & 0.563 & 0.550 & 0.600 & 0.630 \\
\hline & $\beta$ & 0.099 & 0.109 & 0.123 & 0.135 & 0.156 & 0.226 & 0.188 & 0.167 \\
\hline & $\gamma$ & 0.217 & 0.236 & 0.252 & 0.266 & 0.281 & 0.224 & 0.212 & 0.203 \\
\hline & 誤差率 & $37.6 \%$ & $37.2 \%$ & $37.9 \%$ & $37.3 \%$ & $38.6 \%$ & $45.4 \%$ & $44.6 \%$ & $41.8 \%$ \\
\hline \multirow{4}{*}{$\begin{array}{l}\text { 長 } \\
\text { 生 } \\
\text { 圏 }\end{array}$} & $\alpha$ & 0.602 & 0.572 & 0.544 & 0.552 & 0.522 & 0.434 & 0.382 & 0.447 \\
\hline & $\beta$ & 0.271 & 0.281 & 0.288 & 0.278 & 0.284 & 0.354 & 0.404 & 0.327 \\
\hline & $\gamma$ & 0.127 & 0.147 & 0.168 & 0.169 & 0.194 & 0.211 & 0.214 & 0.226 \\
\hline & 誤差率 & $27.0 \%$ & $26.1 \%$ & $26.8 \%$ & $23.4 \%$ & $25.6 \%$ & $31.9 \%$ & $41.2 \%$ & $33.7 \%$ \\
\hline \multirow{4}{*}{$\begin{array}{l}\text { 加 } \\
\text { 茂 } \\
\text { 圈 }\end{array}$} & $\alpha$ & 0.797 & 0.772 & 0.737 & 0.703 & 0.667 & 0.536 & 0.490 & 0.506 \\
\hline & $\beta$ & 0.108 & 0.118 & 0.141 & 0.171 & 0.186 & 0.270 & 0.315 & 0.307 \\
\hline & $\gamma$ & 0.095 & 0.110 & 0.122 & 0.126 & 0.147 & 0.193 & 0.195 & 0.187 \\
\hline & 誤差率 & $30.9 \%$ & $32.6 \%$ & $37.5 \%$ & $44.5 \%$ & $47.3 \%$ & $35.7 \%$ & $49.1 \%$ & $36.4 \%$ \\
\hline \multirow{4}{*}{$\begin{array}{l}\text { 安 } \\
\text { 芸 } \\
\text { 圈 }\end{array}$} & $\alpha$ & 0.851 & 0.838 & 0.813 & 0.796 & 0.785 & 0.652 & 0.599 & 0.590 \\
\hline & $\beta$ & 0.013 & 0.010 & 0.014 & 0.016 & 0.015 & 0.027 & 0.005 & 0.024 \\
\hline & $\gamma$ & 0.136 & 0.151 & 0.173 & 0.187 & 0.199 & 0.320 & 0.396 & 0.386 \\
\hline & 誤差率 & $34.2 \%$ & $35.9 \%$ & $38.6 \%$ & $40.8 \%$ & $41.9 \%$ & $61.7 \%$ & $79.4 \%$ & $72.9 \%$ \\
\hline \multirow{4}{*}{$\begin{array}{l}\text { 児 } \\
\text { 湯 } \\
\text { 圈 }\end{array}$} & $\alpha$ & 0.830 & 0.811 & 0.785 & 0.757 & 0.729 & 0.654 & 0.672 & 0.702 \\
\hline & $\beta$ & 0.015 & 0.016 & 0.021 & 0.022 & 0.030 & 0.058 & 0.053 & 0.049 \\
\hline & $\gamma$ & 0.155 & 0.173 & 0.193 & 0.221 & 0.241 & 0.288 & 0.275 & 0.249 \\
\hline & 誤差率 & $29.4 \%$ & $32.1 \%$ & $35.0 \%$ & $38.1 \%$ & $40.0 \%$ & $40.5 \%$ & $43.9 \%$ & $31.1 \%$ \\
\hline \multirow{5}{*}{$\begin{array}{l}\text { 国 } \\
\text { 頭 } \\
\text { 圏 }\end{array}$} & $\alpha$ & 0.886 & 0.865 & 0.847 & 0.833 & 0.823 & 0.703 & 0.680 & 0.670 \\
\hline & $\beta$ & 0.060 & 0.071 & 0.083 & 0.087 & 0.091 & 0.165 & 0.186 & 0.174 \\
\hline & $\gamma$ & 0.054 & 0.065 & 0.071 & 0.080 & 0.086 & 0.132 & 0.134 & 0.155 \\
\hline & 誤差率 & $35.0 \%$ & $40.5 \%$ & $45.6 \%$ & $46.9 \%$ & $49.8 \%$ & $57.8 \%$ & $48.5 \%$ & $67.1 \%$ \\
\hline & ［通＼cjkstart勤］ & 館林市 & 板倉町 & 明和村 & 千代田町 & 大泉町 & 邑楽町 & & \\
\hline 邑 & $\alpha \quad(2010)$ & 0.731 & 0.635 & 0.463 & 0.435 & 0.788 & 0.477 & & \\
\hline 楽 & $\beta \quad(2010)$ & - & 0.235 & 0.271 & 0.087 & 0.033 & 0.140 & & \\
\hline 圈 & $\gamma \quad(2010)$ & 0.269 & 0.131 & 0.266 & 0.479 & 0.179 & 0.383 & & \\
\hline
\end{tabular}

付与されたウエイト值に差異が認められる。上述のよう に, 邑楽圈では中心市町村以外でも雇用機会が多く存在 する市町村がみられるが，この特徵が各市町村の空間的 位置とも関連しながら典型状態へ付与されるウエイト值 に市町村間で差異を生み出しているものと考えられる。 また, 中心市町村との距離が遠い町村も存在する加茂圈, 中心性に関して中心市町村に肉薄する市町村が存在する 安芸圈や児湯圈, および島嶼村のある国頭圈でも, $\mathrm{x}>\mathrm{y}$ $>_{\mathrm{z}}$ とは異なる順序の場合が目立つ傾向がある。
つぎに，転居に関するウエイト值をみていく。典型状 態 $\alpha, \beta, \gamma$ に付与されたウエイトは, 多くの場合, $\mathrm{x}$ $>\mathrm{y}>\mathrm{z}$ の順序であり, その点は通勤流動の場合と同様で ある。なお, $\mathrm{x}$ 值は通勤の場合に比べて小さく, 反対に $\mathrm{y}$ 值と $\mathrm{z}$ 值は大きい特徴がある。これは, 転居は通勤に比 べて目的地が遠くにあることを意味する。

ただし, ウエイト值の推移は広域圈により異なってお り，通勤流動のような共通性はみられない。転居は通勤 とは異なり, 同居, 施設入所, 就職・転職, 進学, 結婚, 
表 7 広域圈内の人口と通勤者数，転居者数の推移

Table 7 Trend of the population, the number of commuters and that of house movers in the county level areas

\begin{tabular}{|c|c|c|c|c|c|c|c|}
\hline & & & & & & & (単位：人) \\
\hline & $\begin{array}{c}\text { 人口 } \\
1990 \text { 年 }\end{array}$ & $\begin{array}{c}\text { 人口 } \\
2010 \text { 年 }\end{array}$ & $\begin{array}{c}\text { 人口 } \\
2015 \text { 年 }\end{array}$ & $\begin{array}{c}\text { 通勤者数 } \\
1990 \text { 年 }\end{array}$ & $\begin{array}{l}\text { 通勤者数 } \\
2010 \text { 年 }\end{array}$ & $\begin{array}{c}\text { 転居者数 } \\
1995 \text { 年 }-2000 \text { 年 }\end{array}$ & $\begin{array}{c}\text { 転居者数 } \\
2010 \text { 年 }-2015 \text { 年 }\end{array}$ \\
\hline 旭川圈 & 416,741 & 401,536 & 392,745 & 199,866 & 172,842 & 80,800 & 59,658 \\
\hline 旭川市 ・ 当市への流動 & 359,071 & 347,095 & 339,605 & 170,005 & 149,325 & 72,026 & 52,541 \\
\hline 最上圈 & 102,214 & 84,319 & 77,895 & 49,680 & 37,167 & 7,907 & 6,721 \\
\hline 新庄市・当市への流動 & 43,125 & 38,850 & 36,894 & 24,487 & 20,356 & 5,215 & 4,261 \\
\hline 邑楽圏 & 179,698 & 184,276 & 181,672 & 76,236 & 64,574 & 21,380 & 18,316 \\
\hline 館林市・当市への流動 & 76,221 & 78,608 & 76,667 & 31,892 & 28,015 & 11,213 & 8,582 \\
\hline 長生圏 & 145,680 & 156,400 & 149,728 & 55,698 & 46,994 & 14,823 & 11,033 \\
\hline 茂原市・当市への流動 & 83,437 & 93,015 & 89,688 & 35,471 & 29,420 & 10,700 & 7,517 \\
\hline 加茂圏 & 104,552 & 107,772 & 104,903 & 39,688 & 33,681 & 8,575 & 8,378 \\
\hline 美濃加茂市・当市への流動 & 43,013 & 54,729 & 55,384 & 16,308 & 17,270 & 5,052 & 5,486 \\
\hline 安芸圈 & 71,282 & 53,576 & 48,350 & 31,320 & 21,759 & 5,874 & 4,194 \\
\hline 安芸市・当市への流動 & 23,739 & 19,547 & 17,577 & 11,148 & 8,374 & 2,110 & 1,714 \\
\hline 巟湯圈 & 117,438 & 107,003 & 101,901 & 52,500 & 42,675 & 13,260 & 12,590 \\
\hline 西都市・当市への流動 & 37,218 & 32,614 & 30,683 & 16,580 & 12,750 & 3,769 & 3,499 \\
\hline 国頭圏 & 117,996 & 127,813 & 128,925 & 48,708 & 47,831 & 20,471 & 19, 249 \\
\hline 名護市・当市への流動 & 51,154 & 60,231 & 61,674 & 21,915 & 22,059 & 11,585 & 10,112 \\
\hline
\end{tabular}

注）通勤者数や転居者数には，同一市町村内での通勤者数・自宅就業者数や転居者数を含んでいる。

資料：総務省統計局「国勢調查」(1990 年，2010 年，2015 年)。

住み替え, 親からの独立等, さまざまな個別的事情で発 生するが，転居理由により転居先は多様なため，広域圈 の間で転居流動に関するウエイト值の推移の共通性を生 み出しにくいことが，その理由と考えられる。

\section{IV 総 括}

最後に, 典型状態合成法の意義・課題, 本稿から得ら れた知見や今後求められる広域圈の環境整備方向, 等に ついて述べていく。

(1)典型状態合成法の適用により，広域圏内の通勤流動 状況や転居流動状況の年次間 - 地域間比較や変化方向の 把握が的確に行えることが確認でき，本方法の有用性が 実証できた。典型状態合成法には, 実際の流動状況を典 型状態の一次結合で表現しようとした場合に，どの典型 状態に近いのか, あるいは各典型状態のどのようなウエ イトの一次結合によって近似できるのか, さらには，流 動状況が相対的によ゙ういった典型状態に近くなる傾向で 変化しつつあるのかを示すことが可能な特徵があり, 実 際の流動状況を典型状態と対比して検討が行える点は, 関係する市町村（地区）間の流動者比率を単純に集計・ 分析する方法では得られないメリットである。

(2)ただし, 表 6 をみると, 最近になるにつれて, 誤差 率が大きくなる傾向も認められる。これは, 本稿で設定
した 3 つの典型状態の一次結合では, 実際の流動現象を 十分に近似できないことを意味しており，典型状態の設 定内容の吟味が必要であることを示唆している。換言す れば，誤差率の増大は，分析に採用した典型状態の組合 せの妥当性が低下してきたという状況を典型状態合成法 が示している。そのため, 誤差率の改善をはかるうえで は, 典型状態の再検討も必要であろう。たとえば，安芸 圈や児湯圈の場合には, 典型状態 $\beta$ において中心市町村 を 2 つ設定するほうが適当ともいえる。また, 均等流動 $(\gamma)$ については, 均等という概念は重視しながらも, 流動元市町村と流動先市町村との間の距離や, 流動先市 町村の就業機会や人口規模等の要因により流動者数が影 響を受けるという側面も考慮して, 典型状態の流動者数 を調整する方法の採用も検討に值する。

(3)本稿では, 広域圈内の流動現象だけを分析対象とし て取り上げたが，いうまでもなく実際には広域圈外への 流動も存在する。そのため, 広域圈外一の流動も考慮し て, 典型状態合成法の適用範囲を拡大寸ることが今後の 課題である。この点に関しては, たとえば広域圈内の各 市町村からは広域圈外に対してのみ流動が生じていると いう第 4 の典型状態も設定すれば，典型状態合成法は広 域圈外 の流動も分析対象に含めることが可能となる。

(4)通勤に関する中心市町村流動要素值の継続的増大や, 転居に関しても中心市町村流動の要素值が必ずしも低く 
ないことを踏まえると, 中心市町村の一層の施設・生活 環境整備は必要である。また, 前述のように, 広域圈で は周辺市町村も含めて広域圈内全域を対象とした生活機 能の維持・向上をはかるための連携活動が多い状況にあ る。そのため, 広域圈では圈内（特に中心市町村と他市 町村相互間）の交通アクセス条件の整備・改善の必要性 は高い。

(5)ただし, 農村地域の広域圈内で通勤者数の減少が進 行し,また人口減少も一層の進行が予想されるなかでは, 社会資本財の量的拡大には慎重な対応も必要である。そ のため, 今後, 通勤者数や人口の減少が見込まれる地域 では, 広域圈内市町村間のアクセス条件の改善（道路改 良, 交通手段の利便性向上）に力点を置きながら，地域 住民や施設・サービス提供機関がともに往来しやすい環 境を整備していくことが現実的な対応であると考えられ る。

(6)また，通勤と転居の両者において，自市町村内流動 のウエイト值が多くの広域圈のほとんどの時点・期間で 一番高くなっているため, 中心市町村以外の市町村に対 しても継続的な生活環境整備活動が求められる。

\section{注}

注 1) 新田 ${ }^{5)}$ を参照されたい。

注 2) 根岸 ${ }^{6)}$ を参照されたい。

注 3) 国勢調査ですべての市町村相互間の通勤者数や人口移動 者数が把握できるのは 1990 年以降であるため, 本稿でも 1990 年以降の年次を分析対象とした。

注 4) 3 つの条件式を用いた連立方程式から求められるのは, 停 留点の条件を満たす $\mathrm{x}, \mathrm{y}, \mathrm{z}$ の值である。そこで, 実際の 計算では，極小点に関する 2 階の条件も確認するようにし た。

Summary: In this paper, I presented a method to weigh three archetype situations of people flows in order to express the actual people flows in a county level area as a linear combination of the three archetype situations, and applied the method for the analysis of the commuters' flows and house movers' flows. It has become clear that the importance of the areas for commutation has increased since 1990, and, compared with the commuters' flows, the house movers' flows do not have a common trend. Under the condition that the number of commuters does not increase, the quality improvement of the pre-constructed roads in the area is important.

キーワード（Keywords）: 広域圈（County level area）, 通勤（Commutation）, 転居（House moving）, 典型状態（Archetype situation)
注 5) 能美 ${ }^{10)}$ では, 中心地区における自地区内通勤者数を半分に 分けて，それぞれを自地区内通勤者数と中心地区通勤者数 にカウントする措置をとっている。

注 6) ウエイト低下の一要因としては, 自市町村内通勤に含んで いる自宅就業者数の減少が考えられる。ただし，自宅就業 者数を自市町村内通勤には含めない計算結果においても, 多くの広域圈では典型状態 $\alpha$ のウエイトが低下すること が確認された。

\section{引用文献}

1) 国土庁（1972）：『新全国総合開発計画（増補）』．東京.

2) 国土庁（1977）：『第三次全国総合開発計画』. 東京.

3) 国土庁（1987）:『第四次全国総合開発計画』. 東京.

4) 国土庁（1998）:『21世紀の国土のグランドデザイン一地域の 自立の促進と美しい国土の創造一』。東京。

5 ) 新田功（1990）: 地域の活性化と広域生活圈, 明治大学社会科 学研究所紀要, 29(1), 21-49.

6) 根岸裕孝（2013）: 宮崎県における定住自立圈構想の現状と課 題. 宮崎大学教育文化学部紀要, 29, 111-119.

7)宮沢良祐・和田幸信（1996）：人口の移動からみた広域圈の構 造に関する研究，足利工業大学研究集録，22，169-174.

8）菅正史（2010）：1990 年～2005 年の九州圈の通勤構造の分析 を通じた広域計画の課題に関する一考察, 土地総合研究, 2010 年春号, $14-25$.

9）劉作・佐藤誠治・小林祐司・韓鉀洙・李衡橎 - 金貴煥（2003）： 通勤通学流動による地方都市圈の構成と変化に関する研究 その 1 大分県の市町村の場合, 日本建築学会計画系論文集, $564,211-218$.

10)能美誠（2012）：農村地域市町村における社会経済状況と就 業地の関係に関する考察, 農村計画学会誌, $30(4), 579-587$.

(2017 年 6 月 10 日 原稿受理)

(2017 年 10 月 1 日 採用決定) 